\title{
Mishti copes with diabetes: Dancing
}

\author{
Sanjay Kalra, Naresh Kardwal ${ }^{1}$ \\ Department of Endocrinology, Bharti Hospital, ${ }^{1}$ Department of School Health, Civil Hospital, Karnal, Haryana, India
}

I am Mishti, and I live with diabetes. Living with diabetes makes me a self-disciplined girl as I have to follow sensible diet patterns and take my insulin regularly. All these make me a healthy person. At the same time, my health care team asks me to exercise regularly.

In my part of the country, however, girls sometimes find it difficult to access facilities for sports and games. It is an irony that while women contribute the maximum number of medals won by India at international games, my society frowns upon the participation of girls in organized sports and games. This creates a challenge for girls as me, who live with diabetes and need to exercise every day. ${ }^{[1]}$

\section{ENJOYABLE EXERCISE}

To cope with this challenge, my parents and I have found some socially acceptable, and enjoyable, methods of physical activity. These methods are effective, safe and can easily be integrated into a daily routine. They help me improve not only my physical health but also my social and emotional well-being. Thus, I am able to live up to the World Health Organization of holistic health. ${ }^{[2]}$

Participating in such activities allows me to behave as an ambassador for diabetes care and insulin. I am able to prove to myself, and to the rest of the world, those children with diabetes can achieve everything that others can.

\begin{tabular}{|l|l|}
\hline \multicolumn{2}{|c|}{ Access this article online } \\
\hline Quick Response Code: & Website: \\
\hline & www.joshd.net \\
\hline & \\
\hline & \\
\hline
\end{tabular}

\section{DANCING}

My favorite physical activity is dancing. I practice folk dance at least 5 times a week for about $1 / 2 \mathrm{~h}$, with my friends and siblings. I begin by warming up with simple steps and then move on to vigorous movements, before cooling off with light stretching exercises. I try to practice dance forms which involve both upper limb and lower limb movements and include both large and small muscle contractions. This promotes flexibility as well as strength. Such dances also work to increase my insulin sensitivity, so that I need less insulin doses, and keep my nerves, bones, and joints fit. ${ }^{[3]}$ Dances which help me achieve this include Haryanvi folk dance and Bhangra. ${ }^{[4]}$

\section{PRECAUTIONS}

While dancing, I make sure to wear comfortable footwear. I also check my glucose levels, if possible, and take small snack before dancing. My dance mates and coach are aware that I have to take sweets if I feel giddy. Heat exhaustion is another potential danger, especially during hot Indian summers. I overcome this by drinking lemonade, jaljeera, kokum juice, or buttermilk, mixed with salt.

\section{CONCLUSION}

I cope with diabetes by dancing. I feel that folk dance sweeps away my health problems and ushers in good health. I encourage all my friends with diabetes to dance their way to good health.

\footnotetext{
This is an open access article distributed under the terms of the Creative Commons Attribution-NonCommercial-ShareAlike 3.0 License, which allows others to remix, tweak, and build upon the work non-commercially, as long as the author is credited and the new creations are licensed under the identical terms.
}

How to cite this article: Kalra S, Kardwal N. Mishti copes with diabetes: Dancing. J Soc Health Diabetes 2017;5:3-4.

Corresponding Author: Dr. Sanjay Kalra, Department of Endocrinology, Bharti Hospital, Karnal, Haryana, India.

E-mail: bridekarnal@gmail.com 


\section{REFERENCES}

1. Bajaj S, Jawad F, Islam N, Mahtab H, Bhattarai J, Shrestha D, et al. South Asian women with diabetes: Psychosocial challenges and management: Consensus statement. Indian J Endocrinol Metab 2013;17:548-62.

2. Preamble to the Constitution of the World Health Organization as Adopted by the International Health Conference,
New York, 19-22 June, 1946; Signed on 22 July 1946 by the Representatives of 61 States (Official Records of the World Health Organization, No. 2, p. 100) and Entered into Force on; 7 April, 1948.

3. Unnikrishnan AG, Kalra S, Garg MK. Preventing obesity in India: Weighing the options. Indian J Endocrinol Metab 2012;16:4-6.

4. Mundra V. Obesity management: Dancing to the Bhangra beat. Indian J Endocrinol Metab 2012;16:868-9. 